\author{
Natalija Ulčnik \\ Filozofska fakulteta, Maribor
}

\title{
Vpliv Agustičeve publicistične dejavnosti na razvoj knjižne prekmuršcine
}

Imre Agustič (1837-1879), ki ga je slovenska javnost začela spoznavati predvsem v sedemdesetih letih 19. stoletja, ko je v Budimpešti izdajal prvi prekmurski časopis Prijatel (1875-1879), je s svojim publicističnim delovanjem razvijal vse funkcijske zvrsti knjižne prekmurščine: publicistično, umetnostno, strokovno in praktičnosporazumevalno. Kot pisec večine časopisnih prispevkov se je uspešno prilagajal različnim jezikovno-stilnim potrebam in prispeval nekatere inovativne besedne rešitve, nastale predvsem zaradi poimenovalne potrebe pri zvrstni širitvi prekmurskega knjižnega jezika.

Imre Agustič (1837-1879), whose entrance into Slovene public awareness began in the 1870 s when he began publishing the Budapest-based journal Prijatel (1875-1879), developed in his journalistic writing all of the functional registers of a standard Prekmurje language: publicistic, artistic, professional, and practical/communicative. As the author of the majority of the articles in the journal he successfully adapted to various stylistic demands and furnished innovative coinages to meet the need for the stylistic expansion of the Prekmurje standard language.

\section{Uvod}

Imre Agustič je bil edini prekmurski ${ }^{1}$ publicist in pisec 19. stoletja, dobro znan in uveljavljen v razvitem madžarskem meščanskem okolju. Izobrazbo, pridobljeno v sombotelski gimnaziji, je nadgradil s stenografskim izpitom, kar mu je leta 1863, ko je odšel v Budimpešto, ${ }^{2}$ odprlo vrata v državni zbor, kjer je začel svojo poklicno pot kot stenograf. Tam si je pridobil številna osebna in poklicna poznanstva (Just 2006: 13), to pa mu je pomagalo pri uresničevanju zastavljenih življenjskih ciljev, ki so bili vezani predvsem na doseganje družbenega napredka pri preprostih podeželskih ljudeh v obmejni pokrajini današnjega slovenskega prostora, s katerimi ga je družil skupen narodnostni izvor.

$\mathrm{V}$ svojem kratkem, a razgibanem in za tedanje prekmurske razmere vsekakor neobičajnem življenju je posegel na različna področja delovanja, ob publicističnem tudi na literarno, prevajalsko, poljudnostrokovno in politično. ${ }^{3}$ Knjižno prekmurščino, ki je

\footnotetext{
${ }^{1}$ Rojen je bil v Murskih Petrovcih (SBL I: 3).

${ }^{2}$ Stanoval je na levem bregu Donave v ulici Nádor (Egyetértés, 17. 7. 1879, št. 196, II), ki se nahaja v neposredni bližini današnjega Parlamenta (Országház).

${ }_{3}^{3}$ Njegove literarne ambicije so bile sprva opazne v madžarski leposlovni publicistiki (prim. Barbarič 1985), kasneje pa tudi v časopisu Prijatel.

$\mathrm{V}$ madžarščino je prevajal nemško in francosko leposlovje (Poskusna gesla za novi SBL 2000: 19), v poltedniku za kulturo in literaturo, Életképek (Življenjske slike), pa je objavil dve v madžarščino prevedeni prekmurski ljudski pripovedki (Barbarič 1985: 215). Najbrž je v
} 
bila do njegovega nastopa funkcijskozvrstno okrnjena, je s svojo raznovrstno dejavnostjo v relativno kratkem časovnem obdobju izpopolnil in jo, čeprav že v času poenotenja osrednje- in vzhodnoslovenske knjižne norme, ${ }^{4}$ usposobil za različne uporabnostne namene.

\section{Agustičeva publicistična dejavnost v prekmurščini}

Agustičeva publicistična dejavnost je nenehno spremljala in poživljala njegovo $\mathrm{v}$ marsičem togo poklicno pot, ga sprva aktivno vključevala $\mathrm{v}$ madžarsko, ${ }^{5}$ kasneje pa $\mathrm{v}$ slovensko kulturno, družbeno in politično življenje, se prepletala z drugimi področji delovanja ter mu predstavljala življenjski stil.

V obdobju od leta 1875 do svoje smrti ${ }^{6}$ je največ prostega časa in življenjske energije posvetil Prekmurcem namenjenemu časopisu Prijatel, ki ga je začel izdajati 15. septembra 1875 v Budimpešti v $\gg$ Franklin-tivaristva násztavi«. Sprva je izhajal enkrat mesečno, čeprav si je Agustič že od vsega začetka prizadeval za polmesečnik. ${ }^{7}$

prekmurščino prevedel tudi v Prijatelu anonimno objavljena Andersenova Cesarjeva nova oblačila - Nôvi oblêk caszara (Prijatel, 1875, št. 1, str. 6-7) in Jurčičevih Šest parov klobas Sést párov kolbás (Prijatel, 1878, št. 6, str. 23-24).

Od poljudnostrokovnega dela sta pomembni zlasti njegovi knjižici srednjega obsega, namenjeni za šolski pouk, in sicer Návuk vogrszkoga jezika (1876) ter Prirodopis s kepami za národne šole (1878).

Agustič je bil znan tudi kot natančen opazovalec političnega življenja, ki se je v svojem publicističnem delovanju med vsemi Prekmurci največ posvečal politični tematiki. V politiko se je želel še aktivneje vključiti, zato je v murskosoboškem okraju dvakrat kandidiral za državnozborskega poslanca (Trstenjak 2006: 180).

${ }^{4}$ Obe različici slovenskega knjižnega jezika sta se formalno poenotili sredi 19 . stoletja, v praksi pa je bilo poenotenje postopno in nenasilno, zato se je knjižna prekmurščina uporabljala vse do leta 1919, ko se je Prekmurje upravno in jezikovno dokončno združilo s preostalo Slovenijo v skupni državi (Orožen 1996). Sodobno ustvarjanje v prekmurščini, ki je razvito v večini funkcijskih zvrsti, pa po ugotovitvah Zinke Zorko (2005) ponovno prehaja v nadnarečne okvire.

${ }^{5} \mathrm{~V}$ šestdesetih in sedemdesetih letih 19. stoletja je objavljal v številnih madžarskih (pol-) tednikih in dnevnikih, npr. Szegedi Hiradó, Vasárnapi ujság, Gazdasági lapok, Fövárosi lapok, Aradi Alföld, za Magyar ujság pa je bil leta 1869 celo dopisnik iz Boke Kotorske (Barbarič 1985: 215).

${ }^{6}$ Obdobje obstoja prvega prekmurskega časopisa se v literaturi začne zamejevati z letnicama 1875 in 1879 (prim. Szinnyei 1891: 292), natančen podatek o njegovem prenehanju izhajanja pa je prvi podal šele Vilko Novak, ki je navedel, da je časopis nazadnje izšel »dva dni pred urednikovo smrtjo« (Novak 1976: 82), torej 15. julija 1879. Anton Trstenjak, prvi pomembnejši raziskovalec Agustičevega življenja in dela, ki je na svojem potovanju po Prekmurju tudi osebno spoznal Agustičevega očeta, namreč ni podal natančnejših informacij: »'Prijátel' je izhajal malone do smrti Agustičeve« (Slovan, 1885, št. 5, str. 70); »Prva številka je izšla dne 15. septembra 1. 1875., vsak mesec po jedenkrat, pozneje pa, to je 1. 1878., po dvakrat na mesec. /.../ škoda, da je z urednikom tudi list umrl in da ni našel naslednika« (Trstenjak 2006: 180-181).

${ }^{7}$ Gotovo je Agustič poznal slovenske časopise onstran Mure, ki so bili do leta 1875 že precej razširjeni in med katerimi je bilo največ prav polmesečnikov. Slovenski narod, ki je v Mariboru izhajal trikrat tedensko, pa je leto po preselitvi v Ljubljano, tj. leta 1873, postal prvi slovenski dnevnik. 
Izpolnitev želje je videl v porastu števila naročnikov, zato je v prvi številki bralce pozval: »Vszáki ki je 'ze naprêplácso, naj tak dober bode i naj sze toliko potrdí, ka 'Prijátel'-i koncsimár ednoga nôvoga naprêplácsana szprávi z-szvojih znancov, ka bi potom 'Prijátel'-i mogocsno bilô vszáki mêszec dvakrat prihájati« (Prijatel, 1875, št. 1, str. 8). Ugodne okoliščine, ki so omogočile tiskanje štirinajstdnevnika (izhajal 1. in 15. v mesecu), so se izoblikovale šele leta 1877 , Agustič pa se je takrat odločil tudi za spremembo podnaslova iz Znanoszt razserjüvajôcse mêsecsne novine (Znanje šireči mesečnik) v Znanost razšerjüvajoče slovenske novine. ${ }^{8}$

Namen izdajanja časopisa so raziskovalci pogosto povezovali z Agustičevimi političnimi ambicijami - ljudem naj bi se želel prikupiti in si tako pridobiti čim več volivcev (prim. SBL I: 3; Ftičar 1966: 125; Trstenjak 2006: 180). Od navedenega se razlikuje mnenje Franca Š́ebjaniča, da se je Agustič odločil za časopis zaradi iskanja stika z zapostavljenimi in s poniževanimi rojaki, ki so bili nevešči večinskega madžarskega jezika (Šebjanič 1966: 140), kar je skladno tudi z izobraževalno programsko zasnovo časopisa, strnjeno v naslednjem citatu: »Tüdi vu mojem szrci sze je zbüdilo tô 'zelênye, da bi vam jaz vu etom dugoványi edno pôt pokázao, po steroj bi mogli po vrêmeni na visisi sztopáj znanoszti pridti« (Prijatel, 1876, št. 6, str. 1). Natančno poročanje o političnih dogodkih vsekakor potrjuje njegovo zanimanje za politično dogajanje in izraža strokovno razgledanost, ki jo je dosegel kot državnozborski stenograf, a objavljeni prispevki pričajo o odsotnosti politične ali volilne agitacije. Tudi domneva, da je Agustič za izdajanje ilustrativno bogatega časopisa črpal iz strankarskih skladov, se ni potrdila (Barbarič 1985: 218). Agustičeva politična in uredniška funkcija bi vsekakor lahko bili medsebojno povezani, dopolnjujoči - tako z eno kot z drugo je namreč želel pomagati svojim rojakom, za katere je sicer bila značilna nadpovprečna stopnja pismenosti, ${ }^{9}$ a kljub temu nizka stopnja izobrazbe in nerazvita bralna kultura.

Časopis Prijatel je, kakor večina dotedanjih prekmurskih tiskov, začel izhajati $\mathrm{v}$ madžarskem črkopisu, ki je bil glasovno prilagojen prekmurskemu knjižnemu jeziku. ${ }^{10} \mathrm{Ob}$ spodbudah bralcev onstran Mure je Agustič že ob koncu drugega letnika razmišljal o uvedbi slovenice: » Jaz tüdi to miszlim, ka de bogse od vsze szlovenov nücati pravipisz, ar vsze de ji vecs le'ze cstelo« (Prijatel, 1876, št. 12, str. 7). Zanjo se je odločil v začetku leta 1877, in sicer zaradi zavedanja pomembnosti enotnega črkopisa vseh Slovencev ter v upanju, da bo s tem pridobil nove naročnike. ${ }^{11}$ Rabi značilnih prekmurskih zaokroženih glasov $\ddot{u}$ in $\ddot{o}$ se ni odrekel, ${ }^{12}$ kar so mu neprekmurski bralci

\footnotetext{
${ }^{8}$ Jože Ftičar domneva, da je na spremembo podnaslova vplivala želja, služiti vsemu slovenskemu ljudstvu (Ftičar 1966: 126).

${ }^{9}$ Raziskave kažejo, da je bil leta 1880 med vsemi slovenskimi pokrajinami najnižji delež nepismenih prav v Prekmurju (prim. Šircelj 2006: 103).

${ }^{10}$ Trstenjak (2006: 142) je skušal pojasniti izbiro omenjenega črkopisa pri prekmurskih rojakih. Pri tem je menil, da se je madžarski črkopis "prilegal prekmurščini ravno tako, kakor razni slovenski pravopisi pred gajico. V tem oziru so torej onstran Mure ravno tako tavali v temi, kakor tostran Mure bohoričica, metelčica in danjčica«.

${ }^{11}$ Prekmurska publicistika (Kalendar szrca Jezusovoga, Marijin liszt in Novine) se je po Agustiču vrnila k madžarskemu črkopisu in pri njem vztrajala še v začetku 20. stoletja (prim. Jesenšek 2003).

${ }^{12}$ Oba samoglasnika v svojih nadnarečnih besedilih uporabljajo sodobni prekmurski pis-
} 
očitali. ${ }^{13} \mathrm{Z}$ uvedbo slovenice je Agustič tvegal napad madžarske vlade, ki je rabo slovenskega črkopisa odkrito preganjala, saj ga je razumela kot najmočnejšo vez z osrednjeslovenskim prostorom. ${ }^{14} \mathrm{~V}$ tem pogledu se je izkazal kot najdrznejši prekmurski pisec, saj so njegovi sodobniki zaradi previdnosti in v izogib nevšečnostim $\mathrm{v}$ tisku ostajali pri madžarskem črkopisu. ${ }^{15}$

Agustič je upošteval zahteve časa, ki so ob zunanji privlačnosti in priročnosti časopisa zahtevale tudi vsebinsko aktualnost in praktičnost, saj je le zanimiva in pestra ponudba zagotavljala naročnike. Vsebinsko je bil časopis pogojen s svojo programsko zasnovanostjo, objavljeni prispevki pa pogosto razodevajo gmotno in duhovno podobo rodne pokrajine ter sočustvovanje s tamkajšnjim prebivalstvom (Šebjanič 1966: 140). Stalne rubrike, ${ }^{16} \mathrm{v}$ katerih se ob tipičnih poročevalskih besedilih pojavlja tudi poljudnostrokovna in literarna vsebina, so bile skladno s časopisno tradicijo dopolnjene s priložnostnimi rubrikami. ${ }^{17}$ Iz danes le delno ohranjenega časopisa Prijatel, ${ }^{18}$ ki je že v naslovu poudarjal pomen prijateljskih odnosov in strpnosti med narodi, je na vsebinski ravni razvidna urednikova liberalnost, demokratičnost ter njegovi stvarni pogledi na jezik.

\section{Agustičev odnos do maternega jezika}

Agustič se je kot rojen Prekmurec zavedal drugačnosti prekmurskega (knjižnega) jezika, zaradi česar je bilo vključevanje ogrskih Slovencev v javno življenje znotraj

atelji, zapisujejo pa ju tudi v časopisu Porabje (prim. Zorko 2005: 55).

${ }^{13} \|^{\prime}$ 'Prijatel' naj bi opustil pisati neslovanska 'ü' in 'ö'. Teh dveh samoglasnikov ne piše nijeden slovanski narod; zakaj bi ju torej prekmurski Slovenci pisali? Res, da se 'ü' izgovarja v nekaterih besedah, in to ne samo pri prekmurskih, ampak tudi pri drugih Slovencih, toda magjarskega 'ö' pa skoro tudi pri ogerskih Slovencih opaziti nij, čemu ga tedaj v knjige siliti? / .../ V tem obziru naj bi se 'Prijatel' poprijel našega književnega jezika« (Slovenski narod, 27. 3. 1878, št. 70 , str. 3).

${ }^{14} \mathrm{Na}$ omenjeno je opozarjal Anton Trstenjak v Slovanu (1885, št. 5, str. 71): »Znano nam je, da je neki pisatelj v ogrskih Slovencih bil zaradi tega silno preganjan, ker je izdal nabožne vsebine knjižico v slovenskem pravopisu, in da se je o ti nedolžni stvari celo govorilo in razpravljalo v državnem zboru peštanskem ter se naglašalo, da je 'slovenski pravopis' 'most' čez Muro, po katerem se mislijo združiti ogrski Slovenci s štajerskimi.«

${ }^{15}$ Tudi Agustičev sodobnik Jožef Borovnjak, dolgoletni cankovski župnik, je spoznal smiselnost črkopisnega in jezikovnega povezovanja s Slovenci onstran Mure. V knjigah za javno rabo je sicer uporabljal madžarski črkopis, v svojih rokopisnih pesmaricah pa zaradi zasebne rabe predvsem slovenico. Njegovo odkrito povezovanje z neprekmurskimi Slovenci so hitro opazile tudi madžarske oblasti, ki so bile v tej mejni ogrski pokrajini še zlasti pozorne na kakršne koli panslavistične poskuse. Borovnjak je imel tudi hišno preiskavo (Trstenjak 2006: 190), a omenjenih rokopisnih pesmaric, ki bi potrdile njihov sum »veleizdaje«, niso našli in tako so se lahko ohranile do danes.

${ }^{16}$ Vsebinska raznolikost časopisa, pisanega za različne sloje ljudi, je razvidna iz petih stalnih rubrik: Orszácsko szpráviscse/Pregléd, Zvönszki dugoványi, Prepovedávka, Razlocsne glászi in Máli vért.

${ }_{17}$ Npr. portreti (Ravnitelje orsága, Kêpi preimenitásov), odgovori na pisma bralcev (Glászi réditela).

${ }^{18}$ Prva dva letnika sta ohranjena v celoti, in sicer v Budimpešti, Ljubljani in Zagrebu, ob njiju pa NUK hrani še enajsto številko iz leta 1877 in peto, šesto ter sedmo številko predzadnjega letnika. 
ogrskega dela monarhije otežkočeno, in primerjalno z razvitejšimi narodi tudi intelektualne zaostalosti tamkajšnjih prebivalcev. Slednjo je skušal zmanjšati s pomočjo svojega časopisa: »Zmosni národje szvêta májo vnogo novin i knig, steri sze vszáki dén povno'zinávajo; szlovenom 'Prijátel' 'zelé szvojov mocsjov doprneszti vsze ono, ka nyim doszégnoti za volo nyihovoga razlocsnoga jezika (podčrtala N. U.) nê mogocsno « (Prijatel, 1876, št. 4, str. 1). Poudarjal je potrebo po branju v maternem jeziku: »I steri med vami nebi rad po szvojem jeziki (podčrtala N. U.) zvedo vsze ono, ka de sze zgôdilo? « (Prijatel, 1876, št. 7, str. 1). Za takratne razmere drzna odločitev, tiskati slovenski časopis na madžarskih tleh, ki je bila plod urednikovega prepričanja, da ima vsak pravico dobivati informacije $v$ maternem jeziku, je, razumljivo, naletela na odpor. Kljub očitkom je Agustič z neustrašno repliko na naslovnici časopisa Prijatel zagovarjal svojo naklonjenost rojakom: »Ne vidi sze tém hüdovolcom, ka szlovenszki pisem vam. Kak pa te, csi nase lüsztvo drügi jezik nerazmi, scséjo té, ka bi sze znanoszt med nasimi szloveni razsürjávalo? Nasim szlovenom nê szlobodno, po njihovom maternom jeziki (podčrtala N. U.) zvediti zgodjênja szveta? Ki tak prôti gucsijo »Prijatel«-i, tê szo protivnicke nasim szlovenom « (Prijatel, 1876, št. 12, str. 1). ${ }^{19}$

(Knjižno) prekmurščino je v enem prispevku natančneje določil z zvezo vogrski slovenski jezik oz. vogrsko slovensko narečje, pri čemer se ni mogel izogniti sodbi o njeni lepoti in dejstvu o njeni spoštovanosti zaradi kontinuitete s staro cerkveno slovanščino: »Vogrski slovenski jezik je prav lep i osobito od slovenskih učenih ljudi najbolje čislan, kajti oni reko i je tüdi istina da je vogrsko slovensko narečje naj podobnejše staro slovenskemu jeziku« (Prijatel, 1878, št. 6, str. 23). Iz navedenega je jasno vidno, da je Agustič poznal spoznanja osrednjeslovenskih izobražencev o čistosti prekmurščine in da se je tega tudi sam zavedal. Prekmurci zanj niso bili zgolj drugače govoreča skupina ljudi v madžarskem govornem okolju, temveč je bil to njegov prekmurski narod in njegov materni jezik.

Agustičeva odločitev za prekmurščino in madžarski črkopis pa je že po dobrem letu postopoma preraščala $\mathrm{v}$ spoznanje o nujnosti približevanja jezikovnemu stanju onstran Mure, kar je bilo vidno tako v jezikovni podobi časopisa Prijate $^{20}$ kot tudi v njegovem poljudnostrokovnem delu. ${ }^{21} \mathrm{Ob}$ zunanjih spodbudah vzhodnoštajerskih dopisnikov, lastnem spoznavanju aktualnih razvojnih smernic knjižne slovenščine in

${ }^{19} \mathrm{Ob}$ spoštovanju maternega jezika pa je Agustič zagovarjal tudi poznavanje državnega jezika, saj je bil prepričan, da je njuna raba na slovensko-madžarskem jezikovnem in narodnostnem stiku vezana na različne okoliščine sporočanja in se posledično ne izključuje: »Prinasz sze szamo tô 'zelé, ka pôleg szvojga maternoga jezika naj vszaki zná orszacski jezik tüdi. To je na celom szveti tak« (Prijatel, 1876, št. 12, str. 3). Rezultat takega razmišljanja je bila tudi njegova slovnica Návuk vogrszkoga jezika (1876), ki je slovenskim otrokom dajala osnove za učenje madžarščine in, daljnosežno gledano, za izboljšanje socialnega položaja.

${ }^{20}$ Marko Jesenšek (1999: 335-336) je na osnovi jezikovne analize časopisa Prijatel določil tri razvojne težnje: (1) nadaljevanje knjižne tradicije prekmurskih protestantskih in katoliških piscev, (2) vdor nekaterih glasoslovno-oblikoslovnih narečnih prvin, (3) prizadevanja za enoten knjižni jezik, tj. približevanje panonski vzhodnoštajerski knjižni različici in prevzemanje t. i. novoslovenščine. Slednje je vidno šele v zadnjem ohranjenem letniku.

${ }^{21}$ V učbeniku Prirodopis (1878) je opazno terminološko izhajanje iz osrednjeslovenskega jezika, saj se je v tem obdobju že zavedal, da tvorjenje izvirnih naravoslovnih terminov zaradi težnje po poenotenju slovenskega knjižnega jezika ni več potrebno (Jesenšek 1998: 125). 
pomembnosti enotnega črkopisa gre za pričakovan razvoj, ki je bil v določeni meri tudi načrtovan.

\section{Funkcijskozvrstni razvoj knjižne prekmurščine}

Začetni prekmurski tiski (katekizmi, molitveniki, pesmarice, abecedniki) ${ }^{22}$ so, podobno kot osrednjeslovenski, večinoma nastajali zaradi verskih in izobraževalnih potreb. Posvetna tematika, ki je povzročila širitev besednega zaklada in razvoj terminologije, se je v prekmurskem prostoru začela vidneje razvijati šele v 19. stoletju. Ob treh slovnicah (Krátki návuk vogrszkoga jezika za zacsetnike, 1833; Návod na vogrszki jezik, 1871; Návuk vogrszkoga jezika, 1876), nekaj didaktičnih besedilih (Návod na flíszanya vu govorenyi i razményi, 1870; Potikazács na zacsétno rovatanye, 1870; Jezícsna fliszanya, 1871; Návod vu szlovenszke A-B-C-szke i zácsétnoga cstenyá kniga za vucsitele, 1873) in učbeniku Prirodopis (1878) sta takrat nastali dve politično obarvani besedili (Právdeszklenye, 1868; Máli politicsni vodnik, 1869), knjižica omikanega in olikanega vedenja (Zobriszani Szloven i Szlovenka med Mürov in Rábov, 1845), zgodovinsko besedilo (Zgodbe vogerszkoga králesztva, 1848) ter dve etnografski besedili (Sztarisinsztvo i zvacsinsztvo, 1807; Starine železnih ino salaskih Slovenov) (prim. Škafar 1978). V nekaterih tiskih, ob tem pa tudi v rokopisih, se je začela pojavljati tudi izvirna in prevodna poezija, ${ }^{23} \mathrm{ki}$ ob neumetnostnih besedilih dokazuje »določeno razvojno kontinuiteto« prekmurskega leposlovja (Just 2000: 10-11).

Knjižna prekmurščina se je na temeljih razvitega nabožnega slovstva začela vsebinsko in zvrstno širiti, vendar pa lahko šele z Agustičevim nastopom govorimo o razmahu funkcijske zvrstnosti na enem mestu, in to $\mathrm{v}$ času, ko je javna raba prekmurskega jezika postala omejena, saj je bil uradni jezik madžarski. Prvi prekmurski časopis je omogočil razvoj publicistične funkcijske zvrsti, znotraj nje pa so se v prekmurskem prostoru prvič pojavila poročevalska besedila. Vsebinska pestrost časopisa je povzročila tudi razvoj drugih funkcijskih zvrsti, in sicer umetnostne, strokovne ter praktičnosporazumevalne, čeprav je potrebno poudariti, da so medzvrstne meje ponekod zelo rahle in težko določljive. ${ }^{24}$ Agustič je tako dokazal, da je bil prekmurski knjižni jezik sredi 19. stoletja »dobro razvit in sposoben za ubesediljenje vseh funkcijskih zvrsti« (Jesenšek 2008: 101).

Publicistična zvrst se je $\mathrm{v}$ časopisu razvijala na podlagi urednikove primarne želje, naslovniku podati raznovrstne informacije o širšem družbenem življenju, s posebnim poudarkom na notranje- in zunanjepolitičnih dogodkih. Gre za »dokumentarno-zgodovinski prikaz časa in prostora« (Jesenšek 1999: 334), ki se je s pomočjo

${ }^{22}$ Ferenc Temlin: Mali Katechismus (1715); Abecedarium szlowenszko (1725); Mihael Sever: Réd zvelicsánsztva (1747); Števan Küzmič: Vöre krsztsánszke krátki návuk (1754), Nouvi zákon ali testamentom goszpodna nasega Jezusa Krisztusa (1771); Mikloš Küzmič: Krátka summa velikoga katekizmusa (1780), Szlovenszki szilabikár (1780) ... (prim. Škafar 1978).

${ }^{23}$ Začetek prekmurske poezije predstavlja pesem Versus vandalici oz. Slovenska pesem (1774) Davida Novaka (Just 2000: 10).

${ }^{24}$ Tudi v sodobnosti je opazno rahljanje meja med posameznimi funkcijskimi zvrstmi (prim. Bokal 2007). 
različnih vrst besedil uresničeval zlasti v poročevalski podzvrsti. ${ }^{25}$ Posledično so se začela pojavljati posebna jezikovna in stilna sredstva, pri čemer je ob upoštevanju teze o izoblikovanju pravega poročevalskega stila šele $\mathrm{z}$ nastopom dnevniškega ti$\mathrm{ska}^{26}$ možno govoriti zgolj o zametkih poročevalstva v knjižni prekmurščini. Besedila publicistične zvrsti so bila v sedemdesetih letih 19. stoletja žanrsko težko določljiva oz. neizčiščena, kar se kaže v prepletanju njihovih osnovnih značilnosti in spogledovanju z umetnostnim jezikom.

Rubrika o domačih zadevah, ki je bila sprva naslovljena Orszácsko szpráviscse (Državni zbor), od osme številke drugega letnika pa Pregléd, je postavljena na pomembno mesto pod glavo časopisa. V njej je v obliki časopisnega poročila, ki delno spominja na zapisnik, ${ }^{27}$ vsebuje pa tudi značilnosti komentarja ${ }^{28}$ in celo reportaže, ${ }^{29}$ izčrpno podan mesečni pregled političnega dogajanja, zlasti v ogrskem državnem zboru. Od srede drugega letnika je imela pod naslovom zapisan drugi prostorsko-časovni podatek (npr. Budapest, 30-toga mésnyeka), tj. čas urejanja besedila, ki je bil običajno dan pred izdajo.

Pisanje o političnih zadevah, ki je $\mathrm{v}$ povprečju zasedalo dvajset odstotkov časopisnega prostora in je povzročilo prodor politične terminologije $\mathrm{v}$ knjižno prekmurščino, se je nadaljevalo pod rubričnim naslovom Zvönszki dugoványi (Zunanje zadeve). Rubrika je prinašala podrobno poročanje o politično obarvanih dogodkih v tujini, predvsem na Balkanu. Za lažje sledenje različnim novicam so bile vsebinske iztočnice grafično poudarjene, npr. Vu Hercegovini, Vu Szerbii, Nemskoga országa. Zaradi dolgotrajne vojne $\mathrm{s}$ Turki v Srbiji je ob koncu leta 1876 ta rubrika poimenovana $B o ́ j,{ }^{30}$ posledično pa v njej zasledimo bogato vojaško izrazje. ${ }^{31}$ Prav slednje ta besedila povezuje z značilnostmi strokovnega jezika.

${ }^{25}$ Monika Kalin Golob (2003: 46) znotraj publicistične zvrsti uvaja poimenovanje poročevalska podzvrst. Ta se uresničuje v poročevalski besedilih, zanje pa je značilen poročevalski stil. Avtorica med poročevalskimi besedili (nastalimi s poročevalsko dejavnostjo) ločuje: (1) poročevalna besedila (vrsta poročevalskih besedil, temelječa na stvarnem, objektivnem poročanju, s prevladujočo informativno vlogo) in (2) presojevalna besedila (vrsta poročevalskih besedil s prevladujočo interpretativno funkcijo) (Kalin Golob 2003: 51).

${ }^{26}$ Šele takrat je bila slovenščina postavljena pred nalogo »vsak dan kar se da hitro in ažurno (dejavnik časovna stiska) poročati o vedno pestrejšem družbenem življenju, o kopici bolj ali manj podobnih dogodkov (dejavnik enaka, podobna, ponavljajoča se okoliščina) v slovenščini« (Kalin Golob 2003: 64).

${ }_{27}$ Zasledimo natančne podatke o številu prisotnih in odsotnih na sejah državnega zbora ter o izidih glasovanja: »Z-437 poszlavcov je 265 pôleg povoljênya, 60 je prôti szlavalo i 112 poszlavcov je nê na zôcsi bilô« (Prijatel, 1875, št. 2, str. 1).

${ }^{28} \gg$ Po vrêmeni sze 'ze poká'ze, steri je gucso pravico« (Prijatel, 1876, št. 1, str. 2).

${ }^{29} \mathrm{Na}$ slednje kažejo podrobni opisi, s katerimi skuša naslovniku približati dogajanje, npr. »Poszlavci i velikási vogerszkom gvanti, száblyami, érseki i püspöki, ti bogáti vnogo szrbra i zláta noszécsi, szo pred krála sztôpili« (Prijatel, 1875, posk. št., str. 1).

${ }^{30}$ Tako se je imenovala tudi $\mathrm{v}$ ohranjeni številki iz leta 1877 , v številkah naslednjega letnika pa so zaradi konca vojne opazni bolj optimistični naslovi, npr. Konec Turčije, Mir je sklenen, pri čemer je rubrični naslov umaknjen.

${ }_{31} \mathrm{Npr}$. bitje, batalijon, glavni generao, golombis, primérje, szoldacke, prednyi szoldak, zavezek. 
Poročevalski stil se je začel razvijati predvsem v rubriki Razlocsne glászi (Različne novice), kjer so se v vesteh z bolj ali manj natančnim krajevno-časovnim določilom pojavljale raznovrstne zanimivosti ter informacije o nenavadnih vremenskih pojavih, naravnih nesrečah, kaznivih dejanjih (ropih, ponarejanju denarja, umorih, tihotapljenju ...). Vesti o dogodkih iz bližnjih in daljnih krajev je Agustič pisal na osnovi ustnih informacij, ki so jih uvajali t. i. sklicevalni avtomatizmi, npr. glagola praviti in čüti, ${ }^{32}$ ter na podlagi novic iz drugih (pogosto neimenovanih) časopisov ${ }^{33}$ ter dopisov. Slednje je prilagajal in jih opremljal s spremnim avtomatizmom Predlog + kraj + (nam) piše(jo): »Z-Monostra nam pisejo« (Prijatel, 1875, št. 2, str. 8); »ZLendave nam pisejo« (Prijatel, 1876, št. 7, str. 7); »Od törszke granice nam eden prijátel eta pise« (Prijatel, 1876, št. 1, str. 3). V vesteh je bil večinoma uporabljen t. i. izbesedilni panaslov, tj. polkrepki tisk začetnih besed, proti koncu drugega letnika pa so se začeli vse pogosteje pojavljati tudi pravi naslovi, od preostalega besedila ločeni s končnim ločilom:

V-Kalocsi 30-toga mésnyeka 14 vör trplevsi ogen 122 hrámbov zapelío. Nevola je nezgrüntno velika. Pogorévci szo od Haynald érseka 5000 rainskih dobili na pomôcs. (Prijatel, 1875, posk. št., str. 8);

'Zidovje küpijo Palesztino. Edne 'zidovszke novine pisejo, ka od törszkoga sztrána je angluskim 'zidovom, sterim je Törszkiország du'zen, porácsano, naj Palesztino küpijo. 'Zidovje v-ptühinszki országaj szo vküpsztôpili, ka naj eto nyihovo indasnye meszto pá nezáj dobijo. Ali pitanye: jeli májo 'zidovje volô nezáj idti v-Palesztino? ${ }^{34}$ (Prijatel, 1876, št. 9, str. 8).

Znotraj umetnostne zvrsti so se začela razvijala prozna besedila, ki so v časopisu večinoma poimenovana kot pripovedke (prepovedávke), literarnozvrstno pa gre za kratke zgodbe, nastale »po meri in potrebah razvijajočega se časopisja in njegovega literarnega podlistka« (Kos 1996: 164). Zanje je značilna dramska usmerjenost na en dogodek, pri čemer se dogajanje odvija na omejenem prostoru in v kratkem časovnem obdobju, za bralca pa so te zgodbe zanimive zlasti zaradi sodobne motivike in pogosto nepričakovanega konca (prim. Kos 1996: 164). ${ }^{35}$ Agustič je v času pestrega evropskega literarnega dogajanja, ko so se razsvetljenski in romantični toni že prepletali z realističnimi (Just 2006: 16), za svoje bralce pripravljal besedila, s pomočjo katerih jih je lahko razvedril, hkrati pa nanje vplival vzgojno-izobraževalno. Pripovedno dogajanje je načrtno postavil v podeželski svet, s čimer je pri naslovnikih dosegel lažjo identifikacijo ter tako uresničil svoj vplivanjski namen. S kratkimi zgodbami, ki spominjajo na slike iz življenja, priljubljene v tedanji madžarski pub-

32 »Hercegovinanci, kak ete dni glászi právijo, prôti tőrkom sze osztro dr'zijo« (Prijatel, 1875, posk. št., str. 3); »Z-Becsa ete dnih je csüti bilô, ka /.../« (Prijatel, 1876, št. 4, str. 8).

${ }_{33}$ Pri navajanju podatka, kje je urednik dobil informacijo o dogodku, se je pojavljal glagol pisati: »vu Trszti izdécse szlovenszke novine 'Edinoszt' v-szlednyêsem broji eto piso« (Prijatel, 1876, št. 8, str. 6); »Ptühinske novine to pišejo i potrdjávajo, ka /.../« (Prijatel, 1877, št. 11, str. 41).

${ }^{34}$ Retorično vprašanje je v funkciji avtorjevega komentarja.

${ }^{35}$ Kratka zgodba (angl. short story) velja za ameriško različico klasične evropske novele (Kos 1996: 164), zato so opazne njune skupne značilnosti. 
licistiki, oz. na kmetske slike v osrednjeslovenski književnosti, je Agustič "postavil temelje prekmurskemu pripovedništvu« (Just 2006: 16).

$\mathrm{V}$ časopisu se je pojavljala tudi poezija, in sicer ljudske, prevedene in izvirne pesmi, ki so s trohejizacijo verza napovedovale »globlje verznooblikovalne premike« v prekmurski poeziji (Just 2005: 224). Za razliko od večinoma anonimno izdanih proznih besedil je skoraj polovica v Prijatelu objavljenih pesmi podpisanih, med njimi pa ob psevdonimu Morávszki F., ki se pojavi štirikrat, izstopajo tri z inicialkami $a$. $i$. podpisane pesmi z aktualizirano tematiko: Veszélo nôvo leto, Pôvoden in Gorisztánemo. Na podlagi slednjih lahko z gotovostjo trdimo, da je Agustič priložnostno pisal poezijo, istočasno pa lahko sklepamo, da so se njegove pesmi pojavljale tudi $\mathrm{v}$ neohranjenih številkah časopisa.

V navedenih besedilih se je razvijal prekmurski umetnostni jezik, kar je v knjižno prekmurščino prispevalo številne retorične figure, stilno zaznamovano besedje, frazeme, pregovore, elemente humorja, večpomenskost idr. Pogosto so se pojavljali dvogovori, v njih pa prvine sočasne govorjene prekmurščine, ${ }^{36}$ ki so pomenile veliko novost $\mathrm{v}$ primerjavi $\mathrm{z}$ dotedaj razširjenimi verskimi besedili $\mathrm{z}$ arhaično obredno terminologijo.

Môcs lübéznoszti. - Prepovedávka. -

Csernávov szôszed je edno lêpo csér meo. Ne'za je tak lepa bila, kak ti protolêtja prvi szemê, na steroga sze drevja szkrivajôcsi popôvki vöpoká'zejo; tak môdre ocsi mela kak ti pôleg potoka cvetécse korine i vu'zgécse, kak ti med dvöma obláka sztisznyeno szunce; dobrotlivoszt szrcá ino nekrivicsnoszt je olêpilo nyéni obrász (Prijatel 1876, št. 4, str. 5).

Strokovna zvrst je bila v Prijatelu zastopana v praktičnostrokovni podzvrsti. Časopis je obogatila s strokovnim izrazjem, npr. matematičnim, kmetijskim, kulinaričnim, zdravstvenim, tehničnim, upravno-pravnim, med katerim zasledimo tudi avtorjeve in mednarodne neologizme. Pojavljala se je v poučnih člankih, ki so bili del priložnostnih oz. občasnih rubrik in so pogosto izhajali v nadaljevanjih, npr. Od nôvi mertükov, Za lüsztvo potrêbna jesztvina, Kakda sze igle delajo, Vorcanye zemlé-dácse (Kataszter). Strokovna vsebina je v njih podana nazorno in jezikovno razumljivo, $v$ jedrnatem ter dovolj natančnem načinu izražanja, za bralca pomembne besedne novosti pa so pogosto tudi grafično podkrepljene, npr. z razprtim ali s (pol) krepkim tiskom. ${ }^{37} \mathrm{Na}$ praktičnost teh besedil kažejo številni zgledi, ${ }^{38}$ prikazi $\mathrm{v}$ preglednicah ter ponazoritve z ilustracijami.

\section{Kakda sze igle delajo?}

Iglé za sivanye szo ocelnoga drota, ete drot sze na $5-6$ méter velki potács gorzmotovili i ete velki potács drota sze skárjami v-dvojem meszti na dvoje vr'ze. Tê falatja drota sze

${ }^{36}$ »Vi szte János majszter te csi'zmár, jeli bár? - Pito od njega te bogátec. - Jasz szam, nyihova velikoszt: eden pár csi'zm’ zapovêo? - Nê szam záto priso. Da doszta dêc mate? /.../« (Prijatel, 1876, št. 1, str. 6).

37 »Ete francuski nôvi akôv i kebel je hektoliter imé dôbo« (Prijatel 1875, št. 1, str. 3).

38 »Példo denem: csibi rad zazvedo, 328 klafterov koliko méterov i centiméterov zadene, tô sze sz-táble etak nájde« (Prijatel 1875, posk. št., str. 6). 
te escse dvakrat tak na dugo zre'zejo, kak duga igla bode. Skárje masina môcs 'zené i tak sze drot po sztô faláti med skárje tiszka. Skárje v-ednoj minuti 21-krát vre’zejo /.../ 1. kêp. Skér za ednákanye igéo. 2. kêp. Dvoja igla po vövdarjenyi. 3. kêp. Igle po vöbodnyenyi. 4. kêp. Eden zôbi masin za prebodanye. 5. kêp. Prebodanye igéo (Prijatel, 1876, št. 9, str. 6).

Praktičnosporazumevalna zvrst se $\mathrm{v}$ dotedanjih prekmurskih tiskih še ni potrdila. V časopisu Prijatel zasledimo publicistična praktičnosporazumevalna besedila, ki jim je urednik odmeril prostor na zadnji časopisni strani, kjer je v praktično obveščevalnih besedilih naslovnikom sporočal žitne cene. Sčasoma so se ta besedila razvila v natančnejša tržna obvestila, ki so predstavljala zametke malih oglasov in so $\mathrm{v}$ kasnejši prekmurski publicistiki postopno prešla $\mathrm{v}$ oglaševalsko podzvrst publicistične funkcijske zvrsti.

Szilje. Na mraz ino na de'zd'zavnato vrêmen je cêna szilja malo gorszkocsila. Csüdno je, ka csi glih gorice szkoro szo szplój zaprávlene, cêna vina sze ne prezdigáva. Cêna je bila: p s e n i c a 75 kilogramm 'zmécsna 12 rh. $20 \mathrm{kr}$. /.../ o v e s z jáko velko cêno meo po 100 klgr. 9 rh. 94. kr. /.../ (Prijatel, 1876, št. 6, str. 8).

\section{Agustičeve novotvorbe kot rezultat poimenovalne potrebe}

Kakor smo danes, v času skokovitega družbenega in tehnološkega razvoja, pogosto v zagati pri reševanju leksikalnih vprašanj, tako je bil tudi Agustič kot urednik prvega prekmurskega časopisa, ko obstoječe besedišče ni več zadostovalo, postavljen pred težko nalogo, na kar je opozoril že Trstenjak: »Agustič ni imel lahkega posla. Boriti se mu je bilo s samim seboj, to je s slovenskim jezikom, in s sovražniki, kateri njegovega podjetja niso odobravali. Novinarju mu je bilo poročati o vsakdanjih stvareh, in tu se je videlo, kako si je sam pomagal in kako je besede po zraku lovil. Za 'fabriko' si je izkoval besedo 'napravnica', potem pismonosač, podgovorni réditel, pravipis, vsevučistvo. Zanimivo je, kako je iskal besede za 'bralec'. Pisal je v vsaki številki drugače: števec, ščitelj, štitel, čtetel, čtitel. Napravil si je torej petero besed, a naposled mu je najbolj ugajal čtetel« (Trstenjak 2006: 181-182). Zaradi odsotnosti jezikovnih priročnikov v prekmurččini ${ }^{39}$ in neizoblikovane terminologije se je moral pri iskanju ustreznih rešitev največkrat zanesti predvsem ali pa zgolj na lasten jezikovni čut. Razvidno je, da je na določenih področjih občutil neizoblikovanost izbranega jezika, zato se je po svojih zmožnostih lotil tvorjenja novih izrazov. Za potrebe publicističnega izražanja je tvoril številne abstraktne izraze (bantüvanje, djanost, gro'zanye, meranje, nadajanje ...), nastanek novih besed pa je spobujalo tudi poročanje o dotedaj še nepokritih (ali premalo pokritih) strokovnih področjih $\mathrm{v}$ knjižni prekmurščini.

Agustiču kot državnozborskemu stenografu in poslanskemu kandidatu politično življenje ni bilo tuje. Zaradi pestrega političnega dogajanja, o katerem je poročal, a neizoblikovane politične terminologije $\mathrm{v}$ prekmurščini, pa je moral pogosto iskati

${ }^{39}$ Agustič ni imel na voljo nobenega prekmurskega slovarja, obstajali sta zgolj dve znotrajučbeniški zbirki prekmurskih besed, Küzmičeva in Košičeva, ki sta skupaj zajemali 1715 besed, od tega 62 skupnih. To dejstvo bi ga lahko spodbudilo, da je, kot poroča Trstenjak (2006: 182), sam začel pripravljati prekmursko-madžarski slovar. 
ustrezne poimenovalne rešitve: ${ }^{40}$ beranye 'volitve', glavni minister/prednyi minister/ minister predszednik 'predsednik vlade', ${ }^{41}$ levi sztran 'levica', minister (navküpni) zvönszki dugovany/zvönszki minister 'minister za zunanje zadeve', minister notrêsnyi dugovány, minister penez/penez dugovany minister 'finančni minister', minister vadlüvanya 'minister za bogočastje', miniszter vojszke, miniszter vucsenja 'minister za šolstvo', miniszterium poloobdelanya 'ministrstvo za kmetijstvo', minisztersztvo, nazavüpsztvo 'odbor', odeberavec 'volivec', poszlaniksztvo 'odposlanstvo', poszlavcovahi'za 'državni zbor', pravde-podsztava 'zakonski predlog', pravi sztran 'desnica', predszedniksztvo, szedsztvo 'seja, zasedanje', szedsztvo dr'zati 'zasedati', szlavanye 'glasovanje', szlavati, zaberanye 'volitve', zaberati 'voliti', zaberavec/ zabracs/zebracs 'volivec' ... ${ }^{42}$

Seznanjanje bralcev z novostmi na upravno-pravnem področju je na leksikalni ravni Agustiču prav tako predstavljalo izziv: birovija 'sodišče' (birovija krajine), csestni 'uraden' (csestni jezik), csestnik 'uradnik' (csestnik pošte), dacsopoberavnija 'davkarija', dacsopotrosnya 'potrošni davek', dacsoterjas 'davčni izterjevalec', grüntna-kniga 'zemljiška knjiga', katasztralszki 'katastrski' (katasztralszki plüg), kro'zina 'okrožje', kro'zinszki (kro'zinszko nazavüpsztvo), merkacs-vcsenya 'šolski nadzornik', molbeni 'prošnji' (molbeno piszmo), nakaznica (postna nakaznica), navrs 'pribitek', nihavas 'zapustnik', notaros 'notar', notriterjanye 'izterjevanje' (dacse notriterjanye), örok, örocsina 'dediščina', peneznica 'blagajna', penez-szpravlanica 'hranilnica', poberavnija-dacse, szodbeni sztolec 'sodišče', szodbenija/szodbenira 'sodišče', terjas 'izterjevalec', zaperni 'zapisniški' (zaperne knige), zapernik 'tajnik, zapisnikar', zastopnik, zavüpnik 'zaupnik, pooblaščenec', zemledacsa 'zemljiški davek'...

V stalni rubriki Máli vért (Mali gospodar) se je skladno s predmetom obravnave začelo pojavljati kmetijsko izrazje, ki je delno že obstajalo, a ga je Agustič prvi uporabil v knjižnem jeziku: dohan-pov ${ }^{43}$ 'pridelek tobaka', jarno 'spomladi posejano žito', narasztvo 'rastlinstvo', naraszni 'rastlinski', poloobdelanye, poloobdelavec, povar, povas, pôv-szvila, prpeo 'paprika', sadiscse, sadüpovaš, szejaven 'setven', szkrmlavanye 'krmljenje, reja', szlameni 'slamnat'"4 (szlamena szecska), szpovani 'pridelan'...

Pri odpravljanju besednega primanjkljaja je Agustič spretno izkoriščal tudi dejstvo, da lahko obstoječa beseda opravlja več pomenskih nalog: broj 'številka časopisa', gucs 'sestavek, ki se podaja v javnosti', vrednost 'premoženje' ... V časopis je sprejemal tudi prevzete besede (bank 'banka', kapora 'ara' ...), vendar

${ }^{40}$ Pri političnem izrazju je delno sledil tudi Janošu Kardošu (prim. Jesenšek 2007), ki je v prekmurski jezik druge polovice 19. stoletja uvedel veliko (umetnih) novotvorb in načelo etimološke pisave.

${ }^{41}$ V Vodnikovih Lublanskih novicah: pervi minifter (Legan Ravnikar 1997: 479).

${ }^{42}$ Pogoste besedotvorne različice so posledica iskanja ustreznih rešitev pri novih poimenovanjih in so dokaz neustaljene rabe.

${ }^{43}$ Tvorba besed z vezajem kaže na avtorjevo negotovost, ali gre za eno ali dve besedi (pen-cslovek, pocsiv-vremen, vojni-sereg, zemle-gibanye ...).

${ }^{44} \mathrm{~V}$ primerjavi z osrednjeslovenskim besedotvornim sistemom je za Agustiča, kakor tudi za druge prekmurske pisce, značilna drugačna izbira obrazil. 
pa pri njem tujejezičnega vpliva ne zasledimo v večji meri, kot je značilen za druge prekmurske pisce. Pravzaprav je za človeka, ki je deloval v madžarsko govorečem okolju, presenetljivo zavestno izhajanje iz panonskih osnov, kar lahko ponazorimo s samostalnikom napravnica 'tovarna' (napravnica svecs, süknje ...), izpeljanim iz starocerkvenoslovanske osnove: pravъ 'pravi' (prim. Bezlaj 1995: 105) > praviti > napraviti > napravnica. Agustič torej ni prevzel niti madžarske besede (gyar) niti preko nemščine posredovanega latinizma (Fabrik), ki je predvsem v ženskospolski različici značilen še za današnje prekmursko narečje in je izpričan tudi v prekmurskih narečnih slovarjih (prim. Novak 1996, Mukič 2005). ${ }^{45}$

Agustič na splošne neologizme ni posebej opozarjal zaradi njihove pomenske predvidljivosti (npr. domovincsar, pocslovecsanstvo, poloobdelanye). Drugače je ravnal pri širše- ali ožjestrokovnih izrazih, ki jih je v začetnih številkah časopisa ob prvi pojavitvi označil z zvezdico ter pojasnil kot opombe pod črto, in sicer z madžarsko (in nemško) ustreznico:

- »Od nasega poszlaniksztva kotrig je letosz napreprineseno /.../ ka bi vu Buda-Pesti tüdi potrebno bilo edno napravnico*) goriposztaviti za rejenye vojszke skeri« (Prijatel, 1875, št. 1, str. 1)

$*$ Napravnica $=$ gyar $=$ Fabrik;

- »Pod dacso szlisajocse zemle premenkavanye od toga vremena mao za edno leto more sze pri d a c s o p o b e r a v n i j i *) notri povedati« (Prijatel, 1875, št. 1, str. 5)

*Dacso-poberavnija $=$ adoszedo, vagy adohivatal $=$ Steuer Amt;

- »Za vsako okroglino za csistoga dohodka eden nasztop*) sze goriposztavi« (Prijatel, 1875, št. 1, str. 6)

*Nasztop - fokozat;

- »Nede dacsa placsuvena od vu penez-szpravlanico* polo’zeni penez« (Prijatel, 1875, št. 2, str. 6)

*Penezspravlanica $=$ Takarek-penztar.

V kasnejših številkah časopisa pa se na tovrstnih mestih pojavljajo stične sopomenke, npr. »Po taksem je dohana szamoodavanje (monopol), med vnogimi drügimi, nadale osztanolo« (Prijatel, 1876, št. 3, str. 1), »Vu minyen mêszeci v-prvom rédi sztalo za volo szkoncsávanya navküpni dugovány od orszácskoga szpráviscsa zebráno poszlaniksztva (delegácia) tanácsivanye (Prijatel, 1875, št. 1, str. 1), ali opisna pojasnila prevzetih mednarodnih novotvorb: »Eden törszki szoldak /.../ vöpotegno revolver (na vecs sztrlajov pistola)« (Prijatel, 1876, št. 7, str. 2).

${ }^{45}$ Iz Pleteršnikovega Slovensko-nemškega slovarja je razvidno, da se je prevzeta beseda fabrika $\mathrm{v}$ 19. stol. uporabljala $\mathrm{v}$ širšem slovenskem prostoru, vodilka pa uporabnika slovarja usmerja k sopomenki tvornica (fâbrika, f. die Fabrik; - prim. tvornica; it. fábbrica; (tudi: fabríka po nem. Fabrik)). Današnji knjižni izraz tovarna je bil konec 19. stoletja neologizem, prevzet iz češčine: továrna, f. die Fabrik, nk.; - prim. češ. tovarna, Warenlager, Fabrik (Pleteršnik 1894/95). 


\section{Zaključek}

Na temeljih razvitega nabožnega in v manjši meri posvetnega slovstva se je prekmurski knjižni jezik v drugi polovici 19. stoletja potrdil tudi v publicistiki. Zasluge za to ima Imre Agustič, ki je kljub formalnemu poenotenju osrednje- in vzhodnoslovenske knjižne norme za svoj časopis izbral materinščino, tj. prekmurščino.

S prvim prekmurskim časopisom Prijatel, ki je v madžarski prestolnici začel izhajati leta 1875 , so se v prekmurskem knjižnem jeziku ustvarili pogoji za razvoj publicistične funkcijske zvrsti, ob njej pa se je zaradi vsebinske raznolikosti časopisa začela razvijati tudi umetnostna, strokovna in praktičnosporazumevalna zvrst. Agustič se je kot izkušen publicist, prevajalec, pisec strokovnih in priložnostno tudi leposlovnih besedil dobro zavedal jezikovno-stilnih razlik med različnimi besedili, zato se je znal odzvati novim funkcijam primerno. Pri tem je lahko delno izhajal iz obstoječe knjižne tradicije, delno iz govorjenega jezika, pri čemer je izpopolnjeval obstoječa izrazna sredstva in jih prilagajal novim vsebinskim ter jezikovnim zahtevam. Velikokrat pa je moral samostojno reševati poimenovalne potrebe, zato $\mathrm{v}$ časopisu zasledimo številne nove besede in besedne zveze, $\mathrm{s}$ katerimi je obogatil prekmurski knjižni jezik, četudi mu zmeraj ni uspelo ponuditi najprimernejše rešitve.

Zaključimo lahko, da je Imre Agustič s svojim publicističnim delovanjem pomembno vplival na leksikalni razvoj prekmurskega knjižnega jezika in na njegovo jezikovnozvrstno uravnoteženost.

\section{Bibliografija}

Barbarič, Štefan. 1985. Slovenskomadžarski publicist Imre Agustič. Časopis za zgodovino in narodopisje 56/2. 212-221.

Bezlaj, France. 1995. Etimološki slovar slovenskega jezika. Tretja knjiga. P-S. Ljubljana: Mladinska knjiga.

Bokal, Ljudmila. 2007. Terminologizacija publicističnega jezika. Razvoj slovenskega strokovnega jezika. Obdobja 24 - Metode in zvrsti. Ljubljana: Filozofska fakulteta, Oddelek za slovenistiko, Center za slovenščino kot drugi/tuji jezik. 87-98.

Egyetértés, št. 196 (1879), Budapest.

Fliszár, János. 1943. Vend-magyar szótár/Vendiski-vogrszki (vogrszko-szlovénszki, sztáro-szlovénszki) rêcsnik. Budapest.

Ftičar, Jože. 1966. Slovenci na levi in desni strani Mure in njihovi kulturni stiki (do 1919). Panonski zbornik. Murska Sobota. 117-130.

Jesenšek, Marko. 1998. Jezik prekmurskih abecednikov in učbenikov v 19. stoletju. Slovensko-madžarski jezikovni in književni stiki od Košiča do danes. Budimpešta. 121-138.

- - 1999. Jezik v prvem prekmurskem časopisu Prijatel. Logarjev zbornik. Zora 8. Maribor: Slavistično društvo. 327-343.

- - 2000. Oblikovanje publicističnega jezika v slovenskem panonskem jezikovnem prostoru. Slovensko jezikoslovje danes in jutri. Celje. 167-175. 
- - 2003. Prekmurski publicistični jezik v prvi polovici 20. stoletja. Aktualizacija jezikovnozvrstne teorije na Slovenskem. Obdobja 22 - Metode in zvrsti. Ljubljana: Filozofska fakulteta, Oddelek za slovenistiko, Center za slovenščino kot drugi/tuji jezik. 179-189.

- - 2004. Pisava zemljepisnih imen v prvem prekmurskem časopisu Prijatel. Besedoslovne lastnosti slovenskega jezika: slovenska zemljepisna imena. Ljubljana: Slavistično društvo Slovenije. 50-59.

- - 2007. Slovensko panonsko besedje in razvoj slovenskega jezika: Slovenskomadžarsko besedno prepletanje v Agustičevem časopisu Prijatel. Besedjeslovne spremembe slovenskega jezika skozi čas in prostor. Zora 49. Maribor: Slavistično društvo. 188-195.

- - 2008. Prekmurska publicistika 19. in prve polovice 20. stoletja - med knjižno normo in tradicijo. Slavistična revija 56/2. 99-109.

Just, Franci. 2000. Med verzuško in pesmijo. Poezija Prekmurja v prvi polovici 20. stoletja. Murska Sobota: Franc-Franc.

- - 2005. Verzne, kitične in pesemske oblike prekmurskega narečnega slovstva. Prekmurska narečna slovstvena ustvarjalnost. Murska Sobota: Ustanova dr. Šiftarjeva fundacija. 216-234.

- - 2006. Panonski književni portreti 1. Prekmurje in Porabje A-I. Murska Sobota: Franc-Franc. 11-19.

Kalin Golob, Monika. 2003. H koreninam slovenskega poročevalnega stila. Ljubljana: Jutro.

Korošec, Tomo. 1981. O Levstikovem publicističnem jeziku v Napreju. Slavistična revija 29/4. 351-371.

- - 1998. Stilistika slovenskega poročevalstva. Ljubljana: Kmečki glas.

Kos, Janko. 1996. Očrt literarne teorije. Četrta izdaja. Ljubljana: Državna založba Slovenije.

Košič, Jožef. 1992. Življenje Slovencev med Muro in Rabo. Budimpešta.

Košir, Manca. 1988. Nastavki za teorijo novinarskih vrst. Ljubljana: Državna založba Slovenije.

Legan Ravnikar, Andreja. 1997. Pomenske lastnosti upravno-politične in vojaške terminologije v Vodnikovih Lublanskih novicah (1797). Slavistična revija 45/3-4. 477-488.

Mukič, Francek. 2005. Porabsko-knjižnoslovensko-madžarski slovar. Szombathely.

Novak, Franc. 1996. Slovar beltinskega prekmurskega govora. Drugo, popravljeno in dopolnjeno izdajo priredil in uredil Vilko Novak. Murska Sobota: Pomurska založba.

Novak, Vilko. 1976. Izbor prekmurskega slovstva. Ljubljana: s. n.

- - 2006. Slovar stare knjižne prekmurščine. Ljubljana: Založba ZRC, ZRC SAZU.

Orožen, Martina. 1996. Oblikovanje enotnega slovenskega knjižnega jezika v 19. stoletju. Ljubljana: Filozofska fakulteta.

Pleteršnik, Maks. 2006. Slovensko-nemški slovar. Transliterirana izdaja na zgoščenki. Ljubljana: ZRC SAZU, Založba ZRC.

Poskusna gesla za novi Slovenski biografski leksikon. Ljubljana: Založba ZRC, ZRC SAZU. 2000. 
Prijátel. Znanoszt razserjüvajôcse mêsecsne novine. I/posk. št., 1, 2 (1875). BudaPest.

Prijátel. Znanoszt razserjüvajôcse mêsecsne novine II/1-12 (1876). Buda-Pest.

Prijátel. Znanost rašerjüvajoče slovenske novine. III/11 (1877). Buda-Pešt.

Prijátel. Znanost rašerjüvajoče slovenske novine. IV/5, 6, 7 (1878). Buda-Pešt.

Slovan. Leposloven in političen list. I/1 (1884); II/5 (1885). Ljubljana.

Slovenski biografski leksikon I. Ljubljana: Zadružna gospodarska banka. 1925-1932.

Slovenski gospodar. List ljudstvu v poduk. 12/51 (1878). Maribor.

Slovenski narod. 10/294 (1877), 11/70 (1878). Ljubljana.

Snoj, Marko. 2003. Slovenski etimološki slovar. Druga, pregledana in dopolnjena izdaja. Ljubljana: Modrijan.

Szinnyei, József. 1891. Magyar írók élete és munkái. A Magyar tudományos Akadémia megbizázából. I. kötet Aachs-Bzenszki. Budapest. 292.

Šebjanič, Fran. 1966. Novejši književno-zgodovinski in kulturno-politični razvoj v Prekmurju. Panonski zbornik. Murska Sobota. 139-145.

Šircelj, Milivoja. 2006. Rodnost v Sloveniji od 18. do 21. stoletja. Ljubljana: Statistični urad Republike Slovenije.

Škafar, Ivan. 1978. Bibliografija prekmurskih tiskov od 1715 do 1919. Ljubljana: SAZU.

Toporišič, Jože. 1992. Enciklopedija slovenskega jezika. Ljubljana: Cankarjeva založba.

Trstenjak, Anton. 2006. Slovenci na Ogrskem. Narodopisna in književna črtica. Maribor: Pokrajinski arhiv.

Ulčnik, Natalija. 2007. Besedje Agustičevega časopisa Prijatel v Slovarju stare knjižne prekmurščine. Besedje slovenskega jezika. Zora 50. Maribor: Slavistično društvo. 164-176.

Zorko, Zinka. 2005. Prekmursko narečje med Muro in Rabo na vseh jezikovnih ravninah primerjalno z današnjim nadnarečnim prekmurskim knjižnim jezikom. Prekmurska narečna slovstvena ustvarjalnost. Murska Sobota: Ustanova dr. Šiftarjeva fundacija. 47-68.

Prispelo avgusta 2008, sprejeto septembra 2008

Received August 2008, accepted September 2008

\section{Vpliv Agustičeve publicistične dejavnosti na razvoj knjižne prekmurščine}

Prekmurec Imre Agustič (1837-1879) je na podlagi svojih bogatih publicističnih izkušenj začel v madžarski prestolnici izdajati in urejati »znanje šireči« (pol)mesečnik Prijatel (1875-1879). V njem je nadgrajeval knjižno različico svojega maternega jezika, njeno besedišče in besedila pa razvijal v skladu z novimi jezikovnimi in stilnimi funkcijami.

Agustičeva publicistična dejavnost je vplivala na funkcijskozvrstni razvoj knjižne prekmurščine, saj so se začela $v$ njegovem časopisu ob tipičnih 
publicističnih, tj. poročevalskih besedilih pojavljati tudi umetnostna, strokovna in praktičnosporazumevalna besedila, pripomogla pa je tudi $\mathrm{k}$ nastanku strokovnega izrazja področij, ubesedenih v časopisu (npr. politike, vojske, uprave). Pri slednjem je razvidna Agustičeva sposobnost preizkušanja prekmurskih besedotvornih vzorcev, ki jo je spodbujala njegova težnja po razumljivosti, zaradi katere se večinoma ni odločal niti za prevzem razvitejše osrednjeslovenske niti madžarske ali nemške terminologije. Vrlina Agustičevega pisanja je, da se je kot urednik in pogosto tudi pisec vseh časopisnih prispevkov znal izražati različnim funkcijam primerno, pri čemer je največ novosti opaznih v poročevalski podzvrsti publicistične funkcijske zvrsti.

\section{The Influence of Agustič's Publicistic Activity on the Development of Standard Prekmurje Slovene}

Putting to use his rich background as a publicist, the Prekmurje Slovene writer Agustič (1837-1879) published a bi-monthly journal Prijatel (1875-1879) in the Budapest. In the journal he built up a standard variety of his native language, developing its vocabulary in discursive style in step with new demands for stylistic functions.

Agustič's publicistic activity influenced the stylistic development of standard Prekmurje Slovene in that in addition to typical journalistic texts there were also artistic, professional and practical-communicative texts, all of which contributed to the growth of specialized vocabulary that appeared in it (e.g., politics, military, management). In this endeavor Agustič's skill in testing the word-formational patterns of Prekmurje Slovene becomes apparent. Striving for comprehension, he generally eschewed borrowing from better-developed central Slovene, Hungarian or German terminology. The virtue of Agustič's writing manifests itself in his ability as an editor and writer to adapt his style appropriately to various functions. The majority of his innovation is evident in the reporting sub-genre of the publicistic style. 